\title{
Ecomuseums and Contemporary Multi-cultural Communities: Assessing Problems and Potentialities through the Experience of the Écomusée du Val de Bièvre, Fresnes, France.
}

\author{
Elena Montanari*
}

\begin{abstract}
By exploring the distinctive tasks and tools of the ecomuseum paradigm, the essay aims to evaluate the actual and potential role of these institutions within the present context, to investigate their efficiency in operating as progressive tools of knowledge and auto-analysis, and eventually to call into question their ability to 'mirror' the socio-cultural connotation of local communities, which have been highly affected by the accelerated migration of people, objects, cultures and knowledge. The increasingly active engagement of ecomuseums with the 'new members' of their communities, and the enhancement of participation and education activities aimed at fostering their involvement, are introduced through an analysis of the Écomusée du Val de Bièvre, which has been striving to act as an inclusive social agent through the experimentation with innovative collection, representation, education and participation practices.
\end{abstract}

Key words: ecomuseums; multi-cultural communities; reaching-out; participation; education practices.

\section{Exploring the role of ecomuseums in this 'age of migrations': among effective, pending and potential stances}

The theoretical apparatus which has been building the definition of the ecomuseum since the 1970 s has provided the image of a ground-breaking institution which promotes democratic preservation, education and management practices, fosters advanced notions of heritage and identity based on a renovated relationship with places and communities, and operates as a forerunner for the development of an inclusive Museology. ${ }^{1}$

A number of definitions have been forged in order to depict the distinctive features of the ecomuseum - drawing on the heterogeneous conceptions and variations that ensued from different physical, cultural and linguistic contexts (Davis 1999: 78-97). George Henri Rivière (1989: 142) described it as:

A mirror in which a population could seek to recognize itself and explore its relationship to the physical environment as well as to previous generations; also an image offered to visitors to promote a sympathetic understanding of the work, customs and peculiarities of a population.

By referring to its peculiar 'bottom-up and culture-based approach that places community participation and self-actualization at the core of its mission [...], a dynamic approach to museums and heritage preservation that looks forward rather than backwards' (Kreps 2003, 122), Hugues De Varine depicted it as a 'hinge between a heritage and a population' (2004: 6 ), and Peter Davis appointed it as a 'community-driven museum or heritage project that aids sustainable development' (2007: 199).

All these definitions coalesce in the description of a grass-root institution, which disassociates itself from the idea of a static cabinet and widens the narrow focus on procedure and method of traditional museums (Vergo 1989) by promoting a diffused and holistic concept of heritage in the in situ conservation and valorization of the material and immaterial assets of a territory (Corsane and Holleman 1993; Corsane, Davis and Murtas 2009) and, especially, by 
advocating the strengthening of the engagement with the local population ${ }^{2}$. In fact, at the core of the ecomuseum paradigm lies the recognition and enhancement of the social and educational role of museums, and the active participation of the citizens in preservation, interpretation and promotion activities (De Varine 1991). Through the reciprocal commitment of the institution - in representing the local culture and identity - and of the source community - in engaging with a conscious and constant evolution of the museum - the ecomuseum is meant to operate as a 'progressive instrument of knowledge and auto-analysis' (Daccò 2001: 6), reflecting on the past and present history of the population, and helping to build its future (De Varine 2002).

Building on the joint engagement of the inhabitants and a team of specialists, the original model of the ecomuseum was conceived within a progressive museological framework in which these institutions were designed to be run via a continuous dialogue with the citizens, and thus to be constantly upgrading their tasks and tools in parallel with societal transformations (Rivière 1985). By envisioning that the members of the community could be 'moving from the role of consumer to that of actor, and even author of the museum' (Rivière 1989: 164-165), George Henri Rivière imagined that the continuous nourishing of the relationship between the ecomuseum staff and their contemporary society would engender a dynamic institution, that would be revived from generation to generation and could be able to shift the traditional museum paradigm 'toward understanding the public as diverse, plural and active, rather than as a relatively homogeneous and rather passive mass' (Macdonald 2006: 8). This operation should have guaranteed an everlasting process of adaptation to changing social, economical, political and cultural contexts, and provided the possibility to mirror the complex and multicultural evolution of communities.

\section{The evolution of contemporary ecomuseums: from fulfilled premises to suspended tasks}

By observing the evolution of the ecomuseum paradigm through the lens of its theoretical premises, it is possible to acknowledge the fulfillment of some of the original prerogatives and objectives, but also the suspension of some others.

The legacy of the ecomuseum model and its influence in the development of museum practices in the last decades are evident and widely recognized - in the promotion of a holistic and democratic approach to heritage; in the furtherance of an empowered role for museums in linking people, their heritage expressions and places; in the shift of the museums' focus from collection to community, by moving their subject matter based on academic disciplines to an interdisciplinary view of material and immaterial assets; in the experimentation and enhancement of participation practices, reinforcing the involvement of the population at different levels of the museums' work; finally, in the generation of a wide variety of community-based initiatives through the interaction with different physical, social and cultural contexts and/or the coalescence with other models (e.g. the Italian 'museo diffuso'3), which have stimulated the design of more effective museological and management strategies. In particular, within the contemporary context, some of the distinctive features of the ecomuseum structure - site-specific, differentiated, diffused, networked, participated and democratic - are being pointed out and celebrated for their potential to contribute to the development of contemporary museums (Edwards and Bourbeau 2008: 138), whose mission, tasks and instruments are challenged by a range of political, economic, social and cultural phenomena.

In the present context globalization deletes the specificities of territorial assets and raises the necessity for effective strongholds that perpetuate local distinctiveness and sense of belonging; accelerated mobility triggers the shifting and cross-fertilization of identities and thus questions their representations in museums; and the augmented and worldwide movement of objects, images, ideas and information fosters the homogenization of cultures and the dilution of collective memory. Within this framework the institutions responsible for the preservation, promotion and presentation of heritage, memory and identity (i.e. museums and libraries) are required to revise their role, mission and tools. In the last decade major renovation processes have occurred which range from the redefinition of collection strategies, the review of museological and museographical practices (Witcomb 2003; Knell, MacLeod and Watson 2007; Whitehead, Mason and Eckersley 2012; Whitehead, Lloyd, Eckersley and Mason 
2015), the renewal of research and education activities (Hooper-Greenhil 2007), and the redesign of spaces and installations (Basso Peressut, Lanz and Postiglione 2013). The ongoing critical revision of museum policies and practices is meant to enable the role of contemporary museums as social agents (Sandell 2002), through the development of innovative strategies aimed to represent, communicate and interact with a more complex, informed, increasingly inter-connected and multi-cultural population - i.e. to develop more effective and inclusive ways to reach into communities, to give voice to their plural ideas and values, and thus to foster mutual understanding, dialogue and cohesion.

Within this convoluted socio-cultural scenario, the museums drawing on the distinctive features of a place seem to have the potential to awaken the consciousness of memory and identity, temporality and territoriality (Bellaigue 1999: 36). Through their efforts in preserving and valorizing the material signs of history (the visible elements that are part of the physical and mental landscape participating in the construction of cultural identities) and the immaterial traditions (music, folklore, crafts and local knowledge), institutions such as the ecomuseum may pose some resistance to some of the effects of globalization and augmented migrations. They stand against the standardization of space and the homogenization of tangible and intangible culture, weakened by the global recurrence of materials, figures and forms, the acceleration of industrial production and the world-wide diffusion of objects and goods, by contributing to perpetuating and emphasizing the unique characters and values of local heritage - hence operating as strongholds for the distinctiveness of particular cultural sites, objects and manifestations. They participate in the protection of special environments and tokens menaced by destruction or disappearance - acting as presidia of significant places (such as sites bearing archaeological, architectural or historical value) or of dismissed traditions and artisanal know-how (revitalized, for example, through reconstructions, commemorations and educational activities). They fight the dispersion of individual and collective memories through the conservation of sites, objects, images, words, personal stories and knowledge which bear witness to the human history ensuing from a specific environment, by collecting - as archives of memory - and teaching it - as learning centres.

Furthermore, in a context in which social structures, cultural systems and identities are being reconfigured (Appadurai 1996), they have the possibility to foster profound transformations of subjectivity and self-awareness. As Anico and Peralta note (2009: 63), 'In a global scenario of rapid movements, fluxes and changes, heritage arises as a particularly effective resource for asserting continuity and stability, which enables societies to define and anchor their identity'. In particular, the steady historical configuration of artifacts and spaces that seem to anchor this search to secure rooted values ${ }^{4}$, can pose resistance to the disorientation caused by the dynamics of transformative processes, support the re-assessment and the re-appropriation of stable roots in relation to the distinctiveness of local places and historical cultural systems, and recover the undermined relationships with the territory, by shaping the collective and individual need for memories and identification. Within the ecomuseum model, these conservation and celebration strategies are complemented and enhanced by advanced research and education practices, the active involvement of the population in environmental preservation ${ }^{5}$ and, especially, the development of participation practices through which these institutions trigger processes of auto-analysis, nourish a sense of belonging (to spaces or to cultural systems) and foster self-awareness.

These potential contributions of ecomuseums to the re-assertion of identity values within the present context are mainly addressed to the native population; therefore ecomuseums cannot as yet be described as fully inclusive institutions. Contemporary society is characterized by a significant transformation of the socio-cultural composition of communities, which has been significantly augmented and accelerated ${ }^{6}$ by enhanced migration flows developed in the last decade. If the 'evolutive' and dynamic vision theorized by George Henri Rivière was to be fulfilled, it would have allowed the ecomuseums to become outstanding social agents and operative 'contact zones'. Nevertheless, as acknowledged also by Hugues De Varine (2004: 6-7), in general this project was never achieved: it is indeed quite difficult to prove the actualization of the continuous renovation of the relationship between the ecomuseum and its source community.

On the one hand, the present-day period is often absent from the ecomuseums' 
programme - as exhibition and education practices seem to be mainly focused on the historical tangible and intangible heritage. On the other hand, the management of these institutions remains quite exclusive - mainly involving people born in the locality and frequently excluding wide sections of the contemporary population, in particular the 'new members of the community'. As a matter of fact, in the running of ecomuseums it is quite rare to detect the progressive involvement of youngsters (i.e. the new generations) and minority groups (e.g. migrants, refugees, etc.), which would have guaranteed the capacity to represent the transformations of society, the potential to shape culture democratically within indigenous and ethnic communities, and the possibility to offer valuable awareness of the alternative histories that can be found in the same territory. Hence, in general, it is possible to assert that ecomuseums have failed in fulfilling the progressive evolution that was supposed to characterize them, and in upgrading their approaches to meet the new needs of shifting multi-cultural contexts. Today most ecomuseums seem unable to 'mirror' the mutation of present-day societies - and, therefore, miss the opportunity to enhance their sustainable and harmonious development. practices

On the traces of a renovated approach, forging ahead with participation and education

Although several ecomuseums seem to be characterized by non-progressive tendencies, complemented by restricted resources and often stagnant cultural environments, it is possible to detect a rising interest in the implementation of upgraded practices and tools aimed at engaging with the 'new members of the community' and, thus, at enhancing their role and efficacy towards an increasingly multi-layered and multi-cultural society.

These issues are at the core of the major renovation processes which are currently being undertaken by several European museums (Basso Peressut, Lanz and Postiglione 2013). In particular, ethnographic museums are implementing the development of a postcolonial approach (paradigmatic examples illustrating this massive revision wave include the Musée d'Ethnographie de Neuchâtel, Switzerland; Världskulturmuseet in Gothenburg, Sweden; Rautenstrauch-Joest-Museum Kulturen der Welt in Köln, Germany; Musée Royal de l'Afrique Centrale in Tervuren, Belgium). City museums are reacting to ever-changing urban contexts through experimentation with innovative representation and participation practices (leading case studies in the enhancement of the societal role of these institutions include the Museum of London, United Kingdom; Amsterdam Museum, the Netherlands; Historisches Museum Frankfurt, Germany). Migration museums are dealing with the challenges ensuing from the shift of their focus from historical to contemporary migration phenomena (outstanding examples highlighting this evolution include Deutsches Auswandererhaus in Bremerhaven, Germany; Musée de l'Histoire de l'Immigration in Paris, France; Galata-Museo del Mare e delle Migrazioni in Genoa, Italy). These institutions are implementing new museological, museographical and communication strategies to enhance - and, in some cases, to validate - their mission within the contemporary socio-cultural scenario, to include and raise awareness on the plurality of stories, voices and points of view that signify today's cultural identities and, therefore, to improve their ability in relating to and interacting with more complex and diversified audiences.

These renovation processes result in the upgrade of a wide range of aspects within the museums' remit; nevertheless, the actions they are beginning with usually concern the rethinking of representation and narration strategies ${ }^{8}$ and, especially, the development of more aware, multi-vocal and inclusive curatorial practices, focused on the acknowledgment of cultural diversity ${ }^{9}$ and on the search for more conscious, respectful, 'open' and 'pluralistic' display methods.

At a later stage, a diversified array of museums have started to foster their evolution, by progressively adopting participative practices and modeling education activities as instruments supporting the development of inclusive representation strategies - i.e. encouraging the involvement of citizens with different cultural backgrounds in the selection of the themes to be explored and exhibited, in the collection of testimonial objects and stories, as well as in the content production for temporary exhibitions. This experimental inclusive ferment seems to be taking root extensively in several contemporary museums, independently from their scale - including local, regional and national institutions - or thematic focus.

In recent years, participation strategies for community involvement have become a fundamental key issue within the renovation of contemporary museums ${ }^{10}$ and a ubiquitous 
element of heritage management. They are invoked as effective instruments for challenging the authoritative position and the dominant view of the museum as a site of power relations ${ }^{11}$ (Karp et al. 2006), giving voice to the powerless and triggering a process of self-discovery and empowerment in which the curator becomes a facilitator, rather than a figure of authority (Witcomb 2003: 79). They raise further interest in and engagement with the institution from the population, enabling the museum to investigate and meet the real needs of the people, and extending its action to several social categories, including those who are usually not involved or excluded. Ranging from collection to content production, and exploiting traditional or innovative means, participation strategies and practices are being adopted and experimented with by a wide range of different institutions, and thus tested, improved and inflected in a variety of experiences. This is also the case for education activities, which are more and more often used for enhancing the role of museums within a multi-cultural society.

The growing emphasis on learning practices seems to be complemented by the experimentation with innovative strategies and tools, which aim at turning them into more interactive and stimulating experiences - through the implementation of innovative Information and Communication Technologies (Parry 2010:227-228) or the creative exploitation of interplay between various disciplines and artistic languages - or at shaping them into opportunities to promote inclusion and inter-cultural dialogue - through topics and activities which may foster the interest and the involvement of different members of the community (Bodo, Gibbs and Sani 2009).

Notwithstanding the general 'lethargy' of most ecomuseums about these issues, some institutions are starting to develop an operative approach to their shifting socio-cultural contexts. The distinguishing features of the approach of ecomuseums to renovation dynamics do not concern the upgrade of representation practices (i.e. the acknowledgment of contemporary migrations and cross-fertilization phenomena), but rather focus on the involvement of the 'new members of the community' in the education and participative activities they promote.

These efforts emerge in the growing experimentation with such practices - which, in most cases, also trigger the transformation of the functional programme of museum spaces - with the aim to enhance their effectiveness and to foster their capability to involve and deal with a wider and more differentiated audience. These attempts result, for example, in the more focused selection of exhibition themes (e.g. by encompassing such issues as diversity, social and cultural frictions, integration, etc.) or in the integration between traditional and non-conventional practices and tools (e.g. by enhancing the design of inclusive Parish Maps through new technologies). In particular, the intertwining of two of the pillars at the core of ecomuseums' DNA - education and participation - seem to be the most effective strategy to enhance the role of these museums as places for inter-cultural dialogue.

\section{Enhancing contemporary ecomuseums: the experience of the Écomusée du Val de Bièvre}

The efforts promoted by European ecomuseums to improve their role for contemporary societies, to expand their conventional functions, and to engage with new audiences, is an ongoing phenomenon.

The observation of a selection of eloquent case studies - such as Ecomuseo Urbano Metropolitano di Milano Nord (Italy) and Écomusée de Saint Quentin en Yvelines (France), amongst others - highlights that the most advanced experiences can be mapped within urban areas. The institutions operating within, on the border of or in relation to the socio-cultural context of a city are, obviously, more intensely implicated and exposed to the challenges of this 'age of migrations' ${ }^{\prime 2}$ - and, in this regard, more responsive and reactive. Urban ecomuseums seem to be the ones effectively engaging with the involvement of non-traditional audiences (and, especially, youngsters and immigrants), also fostered by well funded networking activities with local associations and institutions.

The predisposition of urban ecomuseums in upgrading their tasks and tools at the service of contemporary society had been theorized in the 1980s by René Rivard (1988). By coining the expression 'combat ecomuseum', he drew attention to those institutions usually located in urban areas, which stand out for their engagement with social issues within past and 
present communities (Davis 1999: 83), and develop a proactive approach to promoting their development. Although there has been a delay in the realization of this model, it is possible to register a growing interest for its implementation due to the potential it holds in relation to the current socio-cultural context.

Some of the issues which in the past specifically and extensively concerned metropolitan areas - with a special reference to migrations and the multi-cultural evolution of communities - today are widely expanded, diversified and diffused also in minor, rural and isolated areas $^{13}$, albeit to a lesser extent. Therefore, the prerogatives, practices and tools of 'combat ecomuseums'-and in particular their approach aimed at fostering the empowerment of museums in acknowledging societal controversial issues, the recognition of both the uniqueness and similarities of different cultures, the stimulation of mutual understanding between the diverse citizens, and the enhancement of dialogue and social cohesion - should become major tasks for all contemporary ecomuseums. This is why it is important to individuate and investigate the experiences of 'trailblazing' ecomuseums which, despite their specific nature, can be regarded as reference models for the development of more inclusive and effective museums - and possibly point out and inspire the shift from apathy to empathy.

One of the most interesting cases, illustrating the use of the principles at the core of the definition of the 'combat ecomuseum' paradigm, is the Écomusée du Val de Bièvre based in Fresnes, on the outskirts of Paris. As widely acknowledged (Davis 1999: 113; Delgado 2001), this institution stands out among other ecomuseums as a forerunner, which was able to strengthen its position as an active social and cultural instrument at the service of the population, by positioning at the core of its mission the urgent societal issues concerning the community inhabiting the Southern area of the Île-de-France region. The interests of the present and future of the population are promoted through an innovative and ambitious programme of temporary exhibitions, participative projects, education activities, and innovative research and collection practices, intended to offer an inclusive representation of local identity, trigger critical debates about societal problems, promote awareness and sense of belonging, and eventually foster inter-cultural dialogue.

The Écomusée du Val de Bièvre, a paradigmatic forerunner for 'combat ecomuseums'

The foundation of the Écomusée du Val de Bièvre can be traced to the original evolutionary process affirming the definition of the ecomuseum paradigm at the end of the 1970s. This institution was conceived within the theoretical framework of the New Museology, and benefited from the enthusiastic contribution of George Henri Rivière and Françoise Wasserman, who supported the transformation of an ancient farm (the Ferme de Cottinville) into a museum operating as a centre for cultural promotion, developing new research and collection activities focused on local material and immaterial heritage, constructing active relationships with the community, and networking with the existing public bodies and organizations. When it started its activities, in 1979, the ecomuseum was dedicated to the valorization of the municipal city (and, therefore, was originally known as Écomusée de Fresnes) and to the investigation and presentation of the rural past of the area and its historical heritage, illustrated through a permanent display. Despite its conventional origins, at the end of the 1990s, the ecomuseum underwent several profound transformations which gradually turned it into a proactive modern institution, promoting a more effective and inclusive relationship with the territory and the community.

The evolution of this ecomuseum was triggered by the redefinition of its mission in relation to a wider and more complex inter-municipal context $(2006)^{14}$. This renovation resulted in the definitive removal of the original permanent display about the history of Fresnes (2009) - whose space was then dedicated to the participative workshops and the exhibitions arising from them - and, thereafter, on the development of a scientific programme entirely based on temporary (and constantly updated) practices.

The overall focus on temporary activities was intended to feed the interest of the people through continuous renovation of the cultural events and activities, and thus to encourage return visits; to widen, enrich and differentiate practices and tasks, designed to meet the needs and the interest of different types of audience, so as to stimulate a broader (and more comprehensive) participation of the population; and, eventually, to reinforce the role of the institution as a place for cultural encounters. Furthermore, the temporary nature of the promoted activities was also conceived to fit the issues related to exhibiting contemporary societal topics (e.g. 
immigration, working conditions, the status of women, citizenship and identity), which are at the core of the ecomuseum mission. On the one hand, due to their multifaceted and constantly evolving character, it is probably not possible to fix these themes into a permanent display. On the other hand, the difficulties in dealing with 'controversial topics' demand a higher level of experimentation: bearing less official bounds than permanent ones, temporary programmes may dare to test controversial propositions, and to implement innovative representation and communication approaches, strategies and tools.

In the last 20 years, the experimentation with advanced practices has built up the role of the Écomusée du Val de Bièvre as a preeminent social agent, mirroring the contemporary local urban society, and encompassing the complexity, the difficulties, and the multifaceted features of its physical and cultural context.

The suburban territory of the Communauté d'Agglomération de Val de Bièvre could be described as a geographical and cultural frontier, lying in between the city and the country, on the one hand straining towards metropolitan dynamics, on the other clinging to its rural past and decentralized position. It is characterized by a lively and diversified economic structure and a heterogeneous demographic frame (including 12 per cent immigrants, according to 2012 surveys by INSEE - Institut National de la Statistique et des Études Économiques), as well as the venue of the main prison in France. In this context, the Écomusée du Val de Bièvre presents itself as a tool aimed at investigating, displaying and promoting local identity, with a particular focus on the topics and the people that usually remain unmentioned and excluded (Wasserman 1995; Delgado 2001; Delarge 2009).

This task is enhanced through various strategies, starting with the choice of the themes that the museum has been exploring and exhibiting since the 1990s. The initiatives promoted have dealt, for example, with the condition of workers throughout the economic crisis - e.g. Quand le travail ne paie plus (When work doesn't pay anymore, 2008) -, with the discrimination against 'people of nomadic origin' - e.g. Insaisissables Voyageurs: Tsiganes (Unseizable Travelers: Romani, 2000) -, with overall identity issues - e.g. En-quête d'Identités (In Search of Identities, 2015) - and with the topics related to immigration and integration, which have been in display several times and analyzed through different lenses - e.g. Rassemblance: un siècle d'immigration en Île-de-France (Resemblance: a century of immigration in Île-de-France, 1993); Paroles de femmes tunisiennes (Words from Tunisian women, 1998); Pieds Noirs ici et la tête ailleurs (Pieds Noirs, feet here and the head elsewhere, 2012).

The most interesting aspects regarding the approach of this institution to such issues as migration, identity and diversity, ensue from the attempt to intertwine the stances of curatorial work and the contents produced through the involvement of the community in all the phases of the ecomuseum's work.

The participation of the population is indeed encouraged and supported through highly experimental practices, via a variety of strategies and tools.

\section{The experience of the Écomusée du Val de Bièvre: embedding participation and education within every museum's activity}

The Écomusée du Val de Bièvre is the promoter of several participative activities; on the one hand they are conceived to support the members of the community in developing further knowledge and awareness, on the other they are aimed at fostering the active contribution of the population to the cultural production and to the representation of local identity offered by the institution.

The core of the multifaceted scientific programme of the ecomuseum ${ }^{15}$ is centered around the organization of long-term temporary exhibitions, intended to explore the heritage, history and main socio-cultural issues characterizing the territory through a thematic approach - this is, through the lens of major societal themes. Drawing on specific issues concerning historical events, heritage assets or elements concerning the citizens' life, these exhibitions aim at tackling stereotypes, making all the members of the community visible, and recognizing the uniqueness and similarities among the different cultures inhabiting the territory (Wassernman 1994; Delarge 2009). The general framework forging these exhibitions is provided by the curatorial work developed by the ecomuseum staff and the scientific board of museologists, 
anthropologists and sociologists who cooperate with the institution. Nevertheless, the design of these events always include the contribution of the members of the community, which may participate in the choice of the topics or in the production of some of the documents on display. Furthermore the ecomuseum tends to always include the voices of the citizens into the displays, by complementing the main narration with the personal stories or the comments which ensued from workshops or interviews, or by exhibiting personal objects and pictures that may have been donated or temporarily lent to the institution. This effort is meant to highlight the plurality of experiences and points of view which the local population at large have developed about specific issues, by valorizing the testimony of those who witnessed a particular historical event - e.g. the integration of French citizens from Algeria, within the exhibition Pieds Noirs ici et la tête ailleurs (2012) - or simply of those who have an idea to share - e.g. the presentation of a selection of voices and images depicting the territory, its problems and potentialities, within the exhibition Parle ma Banlieue. La Val de Bièvre vu par ses habitants (Speak, my Suburb. The Val du Bièvre as seen by its inhabitants, 2006-2007).

The collection of the photographs, words, sound recordings and objects from the citizens, aimed at providing evidence of the tangible and intangible identity signs within the framework of a holistic notion of cultural heritage, is developed in different ways and in relation to several initiatives.

In some cases, the ecomuseum reaches out to the community by operating 'outside the walls' - e.g. organizing special visits to particular areas guided by inter-cultural groups of citizens, developing interviews in the people's houses, or promoting anthropological field research projects, when the analysis of specific sites allows to better understand and document relevant socio-cultural phenomena (such as the 1993 work developed in the block of flats called 'La Lutèce', mainly housing an immigrated population, whose results were portrayed within the exhibition Rassemblance: un siècle d'immigration en Île-de-France).

The ecomuseum also fosters the involvement of the community through specially promoted 'calls'. This strategy was inaugurated by the exhibition Vos objets au musée racontent Fresnes (Your objects in the museum recount Fresnes, 2001), which attempted to reconstruct and present the collective material memory of the territory by displaying a selection of objects that were lent by the population (and previously gathered through public object-raising events). The initiative triggered the development of a new collection methodology, that has now been permanently adopted by the ecomuseum. In fact, in addition to traditional conservation activities -i.e. the collection and archiving of objects, photographs, cards, journals, videos and interviews organized into four specific areas (Communication, Transmission, Life and Social Actions, Architecture and Urbanism) documenting local history, the material culture related to the rural and artisanal past, the physical development of urban areas, sociological transformations, etc. - in 2000 the institution started to develop 'participative collection practices', aimed at including new testimonies narrating the recent history of the territory through the direct contribution of the community. This process is based on the donation of representative objects, each one documented with a description of its history, social value, technical use and anthropological meaning. The documentation is always accompanied by the personal story of the donor, witnessed through interviews and images illustrating the original (physical and cultural) context of the object. Through the combination of material and immaterial - as well as of personal and collective - memories, this 'biographical approach' to the collection contributes to a complex representation of the local identity. On the one hand, these practices trigger significant questions related to self-awareness and sense of belonging - for example, should a Maghrebi immigrant donate an object from his country or one produced in Fresnes? (Delarge 2009: 3). On the other hand, items from people's houses offer an interesting overview of the effects of political, economic and cultural phenomena - e.g. the consequences of globalization on the material culture - and, potentially, of the multi and trans-cultural evolution of the community.

Further participation strategies promoted by the Écomusée du Val de Bièvre concern the short-term 'participative exhibitions' (organized since 2005, from three to five each year) ensuing from the cooperation projects ${ }^{16}$ with local schools, art centers, socio-cultural associations and the Fresnes prison. The partnerships with these institutions, which operate as fundamental mediators fostering the relationship between the museum and the population, are crucial means of involving a wider public and different demographic categories. Through 
these collaborations, the ecomuseum is able to reach out to students, prisoners, refugees, representatives of minority groups - this is, a variety of people, including those 'in difficult situations' and those who usually do not participate, do feel excluded and do not feel represented. Special participative practices are conceived to allow them to become the co-curators and/ or co-authors of the museum, and to contribute to the selection of the investigated topics (normally aimed at raising awareness or promoting critical debates), to the definition of the narration, the production of contents and documents, and the creation of the display. These initiatives often involve groups of youngsters - as in the making of the exhibitions Hip-Hop dixit $^{17}$ (Hip-Hop said, 1991), Lieux incontournables, lieux interdits: 50 jeunes racontent leur ville (Unseizable places, forbidden places: 50 youngsters recount their city, 1998), and Des jeunes s'exposent (Youngsters expose themselves, 2012) - or try to give to different members of the community the possibility to have their stories, memories and points of view expressed in the museum - as in the case of Secondes peaux, secondes vues (Second skins, second sights, 2009), questioning the illusions and stereotypes conveyed by images, or Ma ville vue de ma fenêtre (My town seen from the window, 2011), representing different views on the physical, social and cultural scape of Fresnes through the photos and the complementary comments delivered by the inhabitants.

The construction of these 'participative exhibitions' results from the experimentation with different mediation methods and participation tools. The innovative approach developed by this institution relies on the capacity to enrich and strengthen cooperation practices through the combination of traditional consultation and collaborative strategies with alternative and creative initiatives, based on the intertwining with education stances - which are at the core of the 'Ateliers de l'Imaginaire' (Workshops of the Imagination).

Since 2006, these annual plastic art workshops have been a major activity within the programme of the ecomuseum. They are intended to foster the exploration of local heritage, identity and citizenship through experimentations with artistic practices. Each year, from October to June, four school classes and a group of 15 adults are guided by the ecomuseum staff and special educators (artists or plastic photographers) through an interactive programme aimed at increasing acknowledgment and sense of belonging to the territory by analyzing its features, documenting its elements, and thereafter producing a personal interpretation. These workshops indeed support learning processes at different levels, on the one hand furthering knowledge about local heritage, on the other fostering self-discovery. The educational mechanisms at the base of these initiatives, building on such dynamics as 'learning through participation', 'learning through experience' and 'learning through action', set a particular emphasis on creative and imaginative activities and foster personal expression through practical skills (Coutas and Wasserman 1993) - and, therefore, shape complex experiences (Golding 2009: 4) merging entertainment, education, escape and aestheticism ${ }^{18}$.

The tasks and the values of these initiatives are multifaceted; they operate at various levels and towards different subjects. Primarily, they address the participants, who are offered the opportunity to explore challenging topics dealing with their understanding of the local heritage, memory and identity. Through the support of the practitioners (anthropologists, sociologists, artists and curators) and the efficacy of art languages in triggering auto-reflection and in-depth analysis, participants develop self-awareness and determination. They are given the chance to ask questions and research facts, and they are provided with the instruments to investigate issues, communicate ideas, defeat positions and come to new acknowledgments; thereafter, they are also offered a place (and a platform) to express their voice and points of view. In fact, contents produced within these educational experiences are presented to the public at large (and especially to the other members of the community) in short-term exhibitions - e.g. Images murmurées (Murmured images, 2006), Lieux et histoires de vie (Life places and histories, 2010-11), Territoires à la limite (Territories at the limit, 2011), and L'ordre des choses (The order of things, 2012). The display of these outcomes allows for the sharing of ideas, and thus enhance the ecomuseum's mission in stimulating mutual understanding, offering a plural representation of local identity, and eventually fostering public debate and dialogue ${ }^{19}$. These activities are designed to strengthen the role of the ecomuseum as a forum for community action and a place for multi-cultural - and possibly also inter-cultural - dialogue.

\section{Envisioning the potential of XXIst century ecomuseums}


In the last twenty years, the Écomusée du Val de Bièvre has been consolidating its role as a progressive tool of knowledge and auto-analysis through a special commitment to the enhancement of the traditional ecomuseums' tasks and tools, and a creative experimentation with their characteristic vocation in creating and fertilizing links among education and heritage, past and present, as well as between the museum and the community. Basically, it has advanced the possibility to actualize the role of the ecomuseum conceived by George Henri Rivière as 'a mirror in which the local population views itself to discover its own image' (1989) - as a platform giving voice to the citizens, a forum for community activism, an inclusive social agent and a place for inter-cultural dialogue.

The Écomusée du Val de Bièvre has not been the first - nor probably the most effective - in promoting special projects conceived to engage with multi-cultural audiences, especially if compared with other larger institutions (e.g. city museums and migration museums, but also libraries and public bodies). Nevertheless, it certainly represents a reference model for the ecomuseums which intend to widen their mission by adopting new patterns of cultural transmission, to assimilate the transformation of participative and educative processes, and therefore to upgrade their efficacy towards the contemporary society.

Today the general enhancement of contemporary museums' seem to mainly focus on their ability in contributing to identity building and promoting social and cultural change (Macdonald 2006; Anico and Peralta 2009) - as highlighted by the growing interest for societal tasks in the planning of museum programmes, the convergence between social sciences and museum practices (Fyfe 2006), the rise of sociomuseology (Assunção and Primo 2013), etc. In this framework, the distinctive tools, strategies and uses of heritage that traditionally connote ecomuseums stand out for their salient potential in activating strategies of inclusion and empowerment, and thus in responding to the challenges of convoluted contemporary contexts. These potentialities mainly rely on education activities and tasks, building up issues of territoriality and temporality through the participation of the citizens, promoting mutual understanding, and fostering the construction of a common ground on which to found the harmonious development of multi-cultural societies.

Nevertheless, the interactive and participatory learning experiences used by the Écomusée du Val de Bièvre seem to lead the way to more effective and decisive results. Whilst up until a few decades ago communities were defined by strong 'territorial' and 'relational' parameters (Gusfield 1975), today the population inhabiting the same territory develops interrelations mainly on the basis of territorial assets, and share profoundly different values, habits and views. Within this context, the opportunity for sharing experiences allows for the growth of an 'acquired memory'20 which can trigger the sense of belonging to a physical and cultural environment, foster the 'relational dimension of a community', and stimulate the production of 'cultural energy' (Kleymeyer 1994: 32) - that is, a force generated by shared cultural activities, which can be harnessed to create and reinforce group solidarity, and bolster a community's sense of pride, respect and identity.

Received: 11 October 2014 Finally accepted: 29 June 2015

\section{Notes}

1 According to the International Council of Museums (ICOM), the New Museology represented 'a movement of criticism and reform' aimed at incorporating new developments in the social and human sciences; revitalizing techniques of display, exhibition, and communication; and, ultimately, altering the traditional relationship between the institution and the public.

2 The critical innovation of the ecomuseum project, based on its orientation towards the members of the community and their involvement through participation practices, has been often illustrated through the formula proposed by René Rivard, comparing the definition of traditional museums - 'Museum $=$ building + collections + experts + public' - and ecomuseums - 'Ecomuseum $=$ territory + heritage + memory + population' (Rivard 1988: 124). 
3 For Fredi Drugman the 'museo diffuso' recalls 'the image of a widespread organization, a network of branched museums as a complex system of services primarily responsible for the conservation [...]. A museum that can no longer run out the conservation-information cycle within the old walls of a few building types, but that establishes itself in the strongholds of the territory' (Drugman 1982: 24).

4 As asserted by several scholars, the values conveyed by place itself, especially the heritage place, may represent or stand for a sense of identity and belonging for particular individuals or groups (Davis 1999; Smith 2006; Whitehead, Mason and Eckersley 2012); furthermore, the natural, aesthetic or symbolic features pertaining to specific pieces of environmental heritage seem to possess a 'neutral' character - in that it is likely to be less affected by the relativity and ambivalence connoting other systems of cultural belonging (e.g. religion and politics; Maggi 2001: 7) - which allow museums to build their representation practices on less instrumentalized and more inclusive assets.

5 The increasing acts raised to save local habitats or sites through the active involvement of the population seem to strengthen awareness and sense of belonging (Fitch 1990: 404).

6 The movement of people, objects, cultures and knowledge has always accompanied and fostered the development of the civilizations of the world; throughout the centuries the mobility of individuals and groups, the transfer of materials and goods, and the encounter and integration of different cultural systems significantly contributed to the evolution of human history. Nevertheless, in the last decades the possibilities for physical and virtual travel have gradually improved - and the issues triggering mobility have widened, encompassing not only economic or politic long range movements but also including enhanced touristic flows, professional and study experiences, etc. Therefore, during the twentieth century the migration phenomena started to grow in quantity, rapidity and extent - according to EUROSTAT among the 501 million of people living in Europe in 2010, 47.3 million (9.4 per cent of the total EU population) were born outside their resident country; 31.4 million (6.3 per cent) among them were born outside the EU and 16.0 million (3.2 per cent) in another member state. Among the 61 million people constituting the Italian population, 4.2 million (8.5 per cent of the total population of Italy) were born outside their resident Country; 1.5 million (2.6 per cent) of them were born outside the EU and 3.2 million (5.3 per cent) in another member state. The ongoing accelerated and constantly increasing mobility flows have driven a multi-cultural reconfiguration of the composition of local communities.

7 The acceleration of migration phenomena has significantly augmented the articulation and heterogeneity of the composition of local communities; the continuous assimilation of large amounts of people who were born in other places, bearing highly differentiated familiar codes and cultural backgrounds (in terms of language, religion, rituals, ideas, traditions, alimentary habits, etc.), challenge the demographic, social and cultural structure of the groups living in the same territory. Though the effective integration may require a long and complex process, the immigrants settling down in urban and rural areas for quite long periods enter into the economic and social life of the place, interact with the native population and develop relationships with the environment: they become the 'new members of the community'.

8 The ongoing revisions of museum narratives include the acknowledgment of the role of migration flows, in history and the present, as a fundamental component in the development of a cultural system (as clearly exemplified in some exhibitions promoted by the Museum aan de Stroom in Antwerp, Belgium, and the Musée Dauphinois in Grenoble, France), as well as the exploration of the consequences of cross-fertilization phenomena in the definition of present-day identities (as illustrated in the innovative representation strategies developed by in the Amsterdam Museum, the Netherlands, or the National Museum of Scotland in Edinburgh, United Kingdom). 
9 This commitment can be detected in a variety of strategies, which are developed according to the specific mission, tasks and tools of the different museums. For example, institutions such as national, regional and city museums (this is, the institutions dedicated to the presentation of the history, culture and identity of a nation, a region or a city) are experimenting with the scientific approach and the design of their permanent and temporary exhibitions, in order to integrate the presence of the 'other' cultures which inhabit the territory, to highlight their contributions to local development, and to disclose the exchanges, the frictions and the integration stories ensuing from the cohabitation between autochthonous and immigrant populations (Whitehead, Mason and Eckersley 2012; Basso Peressut, Lanz and Postiglione 2013 Whitehead, Lloyd, Eckersley and Mason 2015).

10 While in the past "rampart "museum professionalism" threatened community involvement in the development of exhibitions and relegated community/museum links to the outreach work of the education department' (Davis 1999: 58), today the inclusion of participative practices is spreading in all types of museums. The rising interest and the increasingly diffused implementation of participation practices (as well as the expectations built upon them) can be detected not only in regard to the evolution of museological strategies, but also in the transformations they trigger within the museums spaces. This phenomenon can be observed, for example, in the design of the newly built museums, where wide spaces are dedicated to cooperative activities, as well as in the re-definition of the functional organization of existing institutions, which more and more often reduce or decommission their permanent exhibitions in order to dedicate specific environments to participation and education practices.

11 The social benefits of involving local communities in heritage management have been highlighted in heritage policy discourses since the 1990s and, thenceforth, they have been widely debated, especially in relation to the issue of cultural production and the political notion of social exclusion/inclusion. The debates vary within a wide range of positions. On the one hand, some state that, in order to achieve such goals as social cohesion or empowerment, local people need to be actively involved in the decision-making that affects the representation of their identity and the development of cultural initiatives in the territory, rather than merely leaving it to professionals implementing top-down representation or regeneration projects. On the other hand, others assume that the importance of the role of curators and heritage professionals is claimed as a guarantee for the scientific value of the cultural offer, as well as a strong position of power - they are 'cultural technicians', thus playing a political role as committed to 'modifying the functioning of culture by means of technical adjustment to its governmental deployment' (Bennet 1998: 185) - because 'museums need to be understood not as institutions which just represent communities and cultures $[\ldots]$ but as institutions which actually produce the very notion of community and culture'. (Witcomb 2003: 80)

12 Migration phenomena have always been concentrated in the cities. This issue can be observed, for example, through the fact that today more then one third of the European population lives in urban areas, as reported by several Research Projects promoted by the European Commission.

13 In the United Kingdom, for example, increasing proportions of new migrants have settled in rural areas, where many are employed in agriculture, food processing and the hospitality sector; in the United Kingdom, the growth rate of immigrant workers in rural areas increased by 186 per cent from 2002 to 2008 (according to a study by Business and Community). In Italy, the percentage of foreign residents in minor districts changed from 2.3 per cent in 2003 to 6.2 per cent in 2011 (according to 'Atlante dei Piccoli Comuni 2012', elaborating figures provided by ISTAT - Istituto Nazionale di Statistica).

14 In 1999 the territory was included in the Communauté d'Agglomération de Val de Bièvre; thereafter, in 2006, the institution re-defined its relationship with the area at an intermunicipal level, extending its research and exhibition practices to an expanded cultural 
perimeter - including seven municipalities, and thus relating to a wider, more complex and heterogeneous population - as reflected in the change of the name to Écomusée du Val de Bièvre.

15 As in other contemporary museums, the programme of the Écomusée du Val de Bièvre is composed of long-term temporary exhibitions - six to twelve months - and short-term temporary activities - from two to three month long exhibitions, to weekly seminars or one-day events.

16 The Écomusée du Val de Bièvre has developed profitable relationships with the territory, also in the form of network programmes with other institutions and associations. It also shares its location with a national school of music, the Regional Conservatory, and the local theatre, the Grange Dimière; this spatial cohabitation is representative of the cooperative approach which characterizes the ecomuseum, fostering and benefiting from the network with several local cultural institutions.

17 The selection of the themes and the means plays a crucial part in the involvement of special social categories (especially among non-traditional museum goers). For example, the exhibition Hip-Hop dixit (1991) ensued from the fruitful collaboration with a wide group of youngsters who helped in developing the focus on the 'hip-hop' culture, and on the use of dance, music and graffiti painting to present this special creativity to a wider audience.

18 Within their 'Experience Economy' studies, Pine and Gilmore asserted that an experience can be envisaged as having four 'realms': entertainment (pertaining to the ludic aspects of workshop activities); education, which requires the active participation of the individual (atelier practices are led individually and intend to foster auto-analysis and personal expression); escapism, which entails the active immersion in the experience (the educative goals of atelier practices are centered on the experimentation with artistic techniques); and aestheticism (atelier practices are developed around artistic based activities). (Karp et al 2006: 78)

19 As theorized by Eilean Hooper-Greenhill in her definition of the 'post-museum' (HooperGreenhill 2000), exhibitions should be conceived as a primary means for providing the visitor with opportunities for learning, raising awareness and furthering the understanding of the contemporary world.

20 In Illuminations, Walter Benjamin defined 'transmitted memory' as the knowledge handed from one generation to the next (an educational heritage that includes history and the way in which it is taught), and distinguished it from 'acquired memory', or lived memory, which is implemented through direct (thus individual) experiences. Contemporary societies, characterized by the coalescence of people with different origins and backgrounds, may rely on the construction of the latter to build up sense of community.

\section{References}

Assunção, P. and Primo, J. (eds) (2013) To Think Sociomuseologically, North Charleston: CreateSpace Independent Publishing Platform.

Anico, M. and Peralta, E. (eds) (2009) Heritage and Identity: Engagement and Demission in the Contemporary World, London \& New York: Routledge.

Appadurai, A. (1996) Modernity at Large. Cultural Dimensions of Globalization, Minneapolis: University of Minnesota Press.

Basso Peressut, L., Lanz, F. and Postiglione, G. (eds) (2013) European Museums in the 21st Century: Setting the Framework - Vol. 1-3, Milan: Politecnico di Milano. 
Bellaigue, M. (1999) 'Globalization and Memory', International Journal of Heritage Studies, 5 (1) $35-43$.

Bodo, S., Gibbs, K. and Sani, M. (eds) (2009) Museums as Places for Intercultural Dialogue: Selected Practices from Europe, Dublin: MAP for ID Group.

Corsane, G. and Holleman, W. (1993) 'Ecomuseums: A brief evaluation', in Robert De Jong (ed) Museums and the Environment, 111-125, Pretoria: Southern Africa Museums Association.

Corsane, G., Davis, P. and Murtas, D. (2009) 'Place, Local Distinctiveness and Local Identity: Ecomuseum approaches in Europe and Asia', in Marta Anico and Elsa Peralta (eds) Heritage and Identity: Engagement and Demission in the Contemporary World, 47-62, London \& New York: Routledge.

Coutas, E. and Wasserman, F. (1993) 'Réel et réalités: l'atelier de l'imaginaire', Musées et Collections Publiques de France, 199, 26-29.

Davis, P. (1999) Ecomuseums. A Sense of Place, London and New York: Leicester University Press.

Davis, P. (2007) 'Ecomuseums and Sustainability in Italy, Japan and China. Concept Adaptation Through Implementation', in Simon Knell, Suzanne MacLeod, and Sheila Watson (eds) Museum Revolutions. How Museums Change and are Changed, 198214, London and New York: Routledge.

Davis, P. (2008) 'New Museologies and the Ecomuseum', in Brian Graham and Peter Howard (eds) The Ashgate Research Companion to Heritage and Identity, 397-414, Aldershot: Ashgate.

Daccò, G. (2001) 'Le mappe smisurate degli ecomusei', Nuova Museologia, 4, 5-9.

De Varine, H. (1991) L'initiative communautaire: recherche et experimentation, Savigny-leTemple: M.N.E.S.

(2002) Les racines du futur: le patrimoine au service du développement local, Chalon sur Saône: ASDIC.

(2004) 'Museo evolutivo o museo a termine?', Nuova Museologia, 10, 6-7.

Delarge, A. (2001) 'Participation: A Community Regulates its own Heritage', ICOM News, 1, 8.

(2004) 'La participation, pierre angulaire et moteur des écomusées', Musées et Collections Publiques de France, 243 (3) 26-28.

(2009) 'Entretien avec Alexandre Delarge, Engagement et participation de l'Ecomusée du Val de Bièvre', in Expologie, (Août-Octobre) 1-4 http://ddata.overblog.com/xxxyyy/2/26/81/51/Entretien-avec-Alexandre-Delarge.pdf.

Delgado, C. (2001) 'The Ecomuseum In Fresnes: Against Exclusion', Museum International, 53 (1) $37-41$.

Drugman, F. (1982) 'Il museo diffuso', Hinterland, 21-22, 24-25.

Edwards, G. and Bourbeau, M. L. (2008) 'Defining a Research Agenda for City Museums in a Peripheralizing World', in lan Jones (ed) City Museums and City Development, 110-128, New York: AltaMira Press. 
Fitch, J. M. (1990) Historic Preservation: Curatorial Management of the Built World, Charlettesville and London: University Press of Virginia.

Fyfe, G. (2006) 'Sociology and the Social Aspects of Museums', in Sharon Macdonald (ed) A Companion to Museum Studies, 33-49, Oxford and Malden: Blackwell.

Golding, V. (2009) Learning at the Museum Frontiers, Farnham: Ashgate.

Hooper-Greenhill, E. (2000) Museums and the Interpretation of Visual Culture, London \& New York: Routledge.

(2007) Museums and Education: Purpose, Pedagogy, Performance, London \& New York: Routledge.

Hubert, F.(1987) ‘Du réseau de musées à l'écomusée', Ethnologie française, 17 (1) 67-74.

Karp, I., Mullen Kreamer, C. and Lavine, S. (eds) (1992) Museums and Communities: The Politics of Public Culture, Washington: Smithsonian Institution Press.

Karp, I., Kratz, C. A., Szwaja, L. and Ybarra-Frausto, T. (eds) (2006) Museum Frictions: Public Cultures, Global Transformations, Durham and London: Duke University Press.

Kleymeyer, C. (ed) (1994) Cultural Expression and Grassroots Development, London: Lynne Reinner Publisher.

Knell, S., MacLeod, S. and Watson, S. (eds) (2007) Museum Revolutions. How Museums Change and are Changed, New York: Routledge.

Kreps, C. (2003) Liberating Culture: Cross-Cultural Perspectives on Museums, Curation, and Heritage Preservation, Abingdon \& New York: Routledge.

Macdonald, S. (ed) (2006) A Companion to Museum Studies, Oxford and Malden: Blackwell.

Maggi, M. (2001) 'Ecomusei, musei del territorio, musei di identità', Nuova Museologia, 4, 9-11.

Nora, P. (1989) 'Between Memory and History: Les Lieux de Mémoire', Representations, $26,7-24$.

Parry, R. (2010) Museums in a Digital Age, Abingdon \& New York: Routledge.

Rivard, R. (1988) 'Museums and Ecomuseums: Questions and Answers' in John Aage Gjestrum and Marc Maure (eds) Okomuseumboka-Identitet, Okologi, Deltakelse, 123-128, Tromso: ICOM Norway.

Rivière, G. H. (1985) 'The Ecomuseum: An Evolutive Definition', Museum, 37 (4) 182-183.

(ed) (1989) La museologie selon Georges Henri Rivière, Paris: Dunod.

Sandell, R. (ed) (2002) Museums, Society, Inequality, London and New York: Routledge.

Vergo, P. (1989) The New Museology, London: Reaktion.

Wasserman, F. (1994) 'L'exposition peut-elle être un outil pour lutter contre l'exclusion: la mise en exposition des minorités à l'Écomusée de Fresnes), in Vagues. Une Anthologie de la Nuovelle Muséologie, (2) 293-301. 
(1995) 'Museums and Otherness. The Community Challenge of the Écomusée de Frsnes', ICOM News, 48 (4) 7.

Whitehead, C., Eckersley, S. and Mason, R. (2012) Placing Migration in European Museums, Milan: Politecnico di Milano.

Whitehead, C., Lloyd, K., Eckersley, S. and Mason, R. (eds) (2015) Museums, Migration and Identity in Europe. Peoples, Places and Identities, Farnham: Ashgate.

Witcomb, A. (2003) Re-Imagining the Museum: Beyond the Mausoleum, London \& New York: Routledge.

\section{*Elena Montanari}

Architect and Ph.D. in Interior Architecture and Exhibition Design, Elena Montanari graduated from Politecnico di Milano where she is currently Adjunct Professor of Interior Design at the School of Architecture and Society, and Post-doc Research Fellow at the Department of Architecture and Urban Studies (DAStU). Since 2005 she has been involved in several national and international research projects; from 2011 to 2015 she has contributed to the EU funded Research Project MeLa - European Museums in an age of migrations (www.mela-project.eu).

Elena Montanari

Ph.D Interior Architecture and Exhibition Design

Politecnico di Milano

Department of Architecture and Urban Studies

Piazza Leonardo Da Vinci 26, 20133 Milano, Italy

elena.montanari@polimi.it 